\title{
Capacitance Reduction Using Ripple Suppression Control of Single Phase Energy Stored Quasi-Z-source inverter
}

\author{
Kaspars Kroics ${ }^{1,2}$, Janis Zakis², Oleksander Husev ${ }^{2,3}$ \\ Institute of Physical Energetics ${ }^{1}$, Riga Technical University ${ }^{2}$, Chernihiv National University of Technology ${ }^{3}$
}

\begin{abstract}
The energy stored Quasi-Z-source Inverter (qZSI) allows integrate energy storage in addition to the other energy source mainly for output power smoothening. Single phase inverter suffers from double-frequency power ripple in the input side and also in the energy storage that is transferred there from the ac-side. In qZSI must be used large electrolytic dc capacitors in the impedance network to suppress this $100 \mathrm{~Hz}$, ripple. Also to suppress this ripple can be applied two types of power decoupling: passive power decoupling and active power decoupling. In this paper is analyzed passive power decoupling that is realized by means of the modified control strategy that produces the time-varying shootthough duty cycle to mitigate power ripple without deteriorating of the output power quality. The validity of proposed control strategy was confirmed by simulation results that were obtained in PSIM software.
\end{abstract}

Keywords: passive decoupling, single-phase inverter, PR controller, double-frequency ripple, energy stored quasi-Z source.

\section{INTRODUCTION}

The cost of electricity produced by renewable energy sources and probabilistic nature of the generation are major concerns that limits its wider usage. Storage technologies have big potential for smoothing out the electricity supply from these sources and ensuring that the supply of generation matches the demand. Typical solution for energy storage integration in renewable energy system is to use additional dc-dc or even dc-ac converter that increases costs [1], [2]. More and more popular are becoming multiport dc-dc converters that can be used for integration of energy source and battery or different types of storages into the grid. Usually, a multiport converter is used in combination with traditional dc-ac converter. Further possible reduction of size, costs and losses can be obtained with the development of novel multiport dc-ac single stage converters having less semiconductor switches and passive elements [3]. Such type of the converter can be designed with reduced number of components and smaller size. One of the possible topology that allows integration is quasi-Z-source inverter with integrated storage in parallel to one of the Z-source capacitor. In [4], [5], [6], [7] is compared qZSI topologies to the traditional voltage source inverter with additional boost converter. The results show that the power losses of the semiconductors of the Z-source inverter are higher but the volume of passive elements in some applications and modes can be reduced. Also the number of switches is less that makes practical design of the converter easier. Additional advantages of ZSI is wide-range input voltage regulation possibility along with enhanced reliability.

The benefits of the qZSI can be extended with integration of energy storage into the converter structure without additional passive and semiconductor elements. Scientific papers about this topology are summarized in [8]. Mainly in the literature is analyzed three phase qZSI. In single phase application the bulky capacitors and inductors are needed to limit $100 \mathrm{~Hz}$ pulsations [9], [10] therefore it makes the application of this topology in practical applications unattractive.

In the literature are proposed a few strategies to reduce the double frequency ripple [11], [12]. Passive decoupling is analyzed in [13], [14]. There is no paper that analysis application of this methods to the energy stored qZSI. As the energy storage is connected in parallel to the one of the capacitors the ripple reduction influences input power ripple therefore there must be find some compromise. This paper is dedicated to investigate the passive power decoupling in energy stored qZSI. In this paper approach based on proportional resonant controller will be analyzed.

\section{II.ENERGY STORED QZSI}

Fig. 1. shows schematics of qZSI with integrated battery The battery is connected in parallel to the upper capacitor of the quasi-Z-source inverter, it is possible to control output power, and state of charge (SOC) of the battery at the same time by controlling 
the shoot-through (ST) duty ratio and modulation index [15].

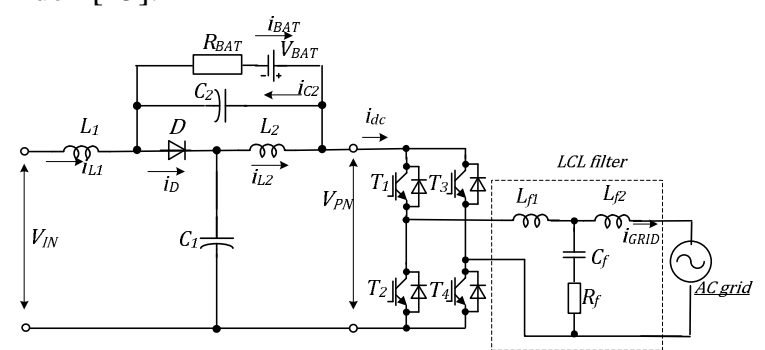

Fig. 1. Quasi-Z source inverter with integrated battery

If the battery is connected in parallel to the upper capacitor $\mathrm{C}_{2}$ then low voltage battery can be used. The converter is controlled by means of full bridge inverter transistors and only one additional diode or transistor is needed to provide operation of the converter. Two inductors and capacitors form quasi $\mathrm{Z}$ source network and by means of shoot through state duty cycle (D) output voltage can be controlled.

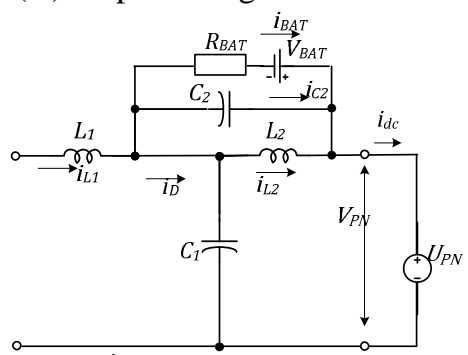

a)

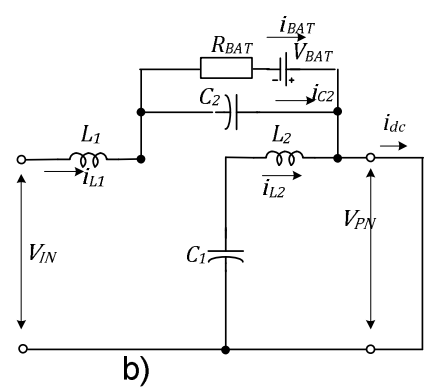

Fig. 2. Equivalent circuits of the converter: (a) - during non shootthrough state; (b) - during shoot-through state

Operation modes of the converter also are shown in Fig. 2. From the equivalent circuit can be derived expressions that describes voltages and currents in particular state. The relation between variables of the converter can be described mathematically by solving equations that describes both states of the converter and taking into account that average voltage of an inductor over one switching period is zero and also average current of a capacitor over one switching period is zero. Expressions are relatively simple and was solved analytically. Must be taking into account that in equations is not taking into account parasitic resistances of all elements, the deeper analysis is provided in [16] and [17]. The final equations for steady-state conditions are as follows:

$$
\begin{gathered}
\mathrm{V}_{\mathrm{C} 1}=\frac{1-\mathrm{D}}{1-2 \mathrm{D}} \mathrm{V}_{\mathrm{IN}} . \\
\mathrm{V}_{\mathrm{C} 2}=\frac{\mathrm{D}}{1-2 \mathrm{D}} \mathrm{V}_{\mathrm{IN}} . \\
\mathrm{V}_{\mathrm{PN} \max }=\frac{1}{1-2 \mathrm{D}} \mathrm{V}_{\mathrm{IN}} .
\end{gathered}
$$

If the battery is connected in parallel to the capacitor $\mathrm{C}_{2}$ and considering that $\mathrm{V}_{\mathrm{BAT}}$ is approximately equal to the $\mathrm{V}_{\mathrm{C} 2}$, the following expression can be derived:

$$
\mathrm{V}_{\mathrm{PN}}=2 \mathrm{~V}_{\mathrm{BAT}}+\mathrm{V}_{\mathrm{IN}} \text {. }
$$

The output power of the inverter can be controlled by manipulating of output voltage, as the output peak phase voltage of the inverter is:

$$
\mathrm{v}_{\text {line max }}=\mathrm{V}_{\mathrm{PN} \max } \cdot \frac{\mathrm{M}}{2},
$$

where $\mathrm{M}$ is a modulation index.

Also for the connection of the battery in parallel to $\mathrm{C}_{2}$ exists battery discharge power limitations [18] that also must be taken into account. The calculation of the parameters of passive components of the quasi Z-source inverter without energy storage is analyzed in many papers for example in [19]-[22]. The difference from traditional qZSI in parameter calculation is that voltage ripple on the capacitors must be lower to limit battery power pulsations it means that passive component values must be higher that in traditional qZSI.

In the single phase system, the power injected in the ac grid can be expressed as follows:

$$
\mathrm{P}=\frac{\mathrm{V}_{\max } \mathrm{I}_{\max }}{2}-\frac{\mathrm{V}_{\max } \mathrm{I}_{\max }}{2} \cos (2 \omega \mathrm{t}) \text {.(6) }
$$

The second term in the equation above causes ripples at the dc side. Therefore, the input power also oscillates with the ac power at $120 \mathrm{~Hz}$. Such oscillating currents and voltages will reduce the photovoltaic array or generator lifetime and will cause degradation of capacitor and increase switching stresses. The ripple can be removed in case if bulky electrolytic capacitors are used but this will results in decrease in power density of the converter.

\section{CONTROL SYSTEM}

The basic principle of the capacitance reduction method can be explained by fact that energy is distributed between capacitors $C_{1}$ and $C_{2}$ according to the voltage variation:

$$
\begin{aligned}
& \Delta \mathrm{E}_{1}=\frac{\mathrm{C}_{1}\left(\mathrm{~V}_{\mathrm{C} 1 \_ \text {max }}^{2}-\mathrm{V}_{\mathrm{C} 1 \_ \text {min }}^{2}\right)}{2}=\mathrm{C}_{1} \cdot \mathrm{V}_{\mathrm{C} 1} \cdot \Delta \mathrm{V}_{\mathrm{C} 1}, \\
& \Delta \mathrm{E}_{2}=\frac{\mathrm{C}_{2}\left(\mathrm{~V}_{\mathrm{C} 2 \_ \text {max }}^{2}-\mathrm{V}_{\mathrm{C} 2 \_ \text {min }}^{2}\right)}{2}=\mathrm{C}_{2} \cdot \mathrm{V}_{\mathrm{C} 2} \cdot \Delta \mathrm{V}_{\mathrm{C} 2},
\end{aligned}
$$

where $\Delta \mathrm{E}$ is the ripple energy that is stored in the capacitor and $\mathrm{V}_{\mathrm{Cmax}}$ and $\mathrm{V}_{\mathrm{Cmin}}$ are the maximum and minimum voltages across the capacitor. According to (7) and (8) there are two ways to increase $\Delta \mathrm{E}$ in 
traditional qZSI. One is to increase the capacitance or use unsymmetrical passive components [23] and the other way is to increase the voltage fluctuation across the capacitors [24], [14] by implementing advanced control system or by using active filter [25]. In the energy stored qZSI the voltage ripple of upper capacitor $\mathrm{C}_{2}$ causes battery current ripple that shortens lifetime of the battery. Instead of increasing the capacitance, the control system can be used that will increase the voltage fluctuation across the input to remove double-frequency ripple from the capacitors. By using this method it is not possible full reduction of voltage ripple but partly the value of capacitance can be reduced improving power density of the converter.

The control structure used in simulations of energy stored qZSI is shown in Fig. 3. As there are three power flows: from PV panel or other energy source, from or to battery and from or to ac grid then by controlling two of them the third one of them is determined [26]. In particular case battery power or input power is controlled by shoot trough duty cycle $\mathrm{D}$ which is controlled by PI algorithm and inverter output power is controlled by modulation index $\mathrm{M}$.

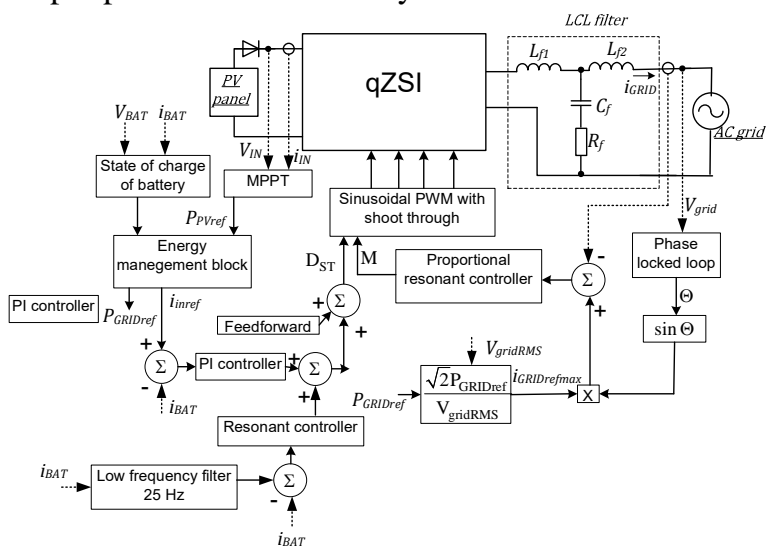

Fig. 3. General control structure of energy stored qZSI

To speed up response and improve stability the feedforward control is used, the average duty cycle can be calculated by equation expressed from previous equations (1) - (5). If the battery is connected in parallel to the upper capacitor $\mathrm{C} 2$ the equation for average duty cycle can be calculated as follows:

$$
\mathrm{D}_{\text {STaverage }}=\frac{\mathrm{V}_{\mathrm{BAT}}}{\mathrm{V}_{\mathrm{IN}}+2 \mathrm{~V}_{\mathrm{BAT}}},
$$

The inverter side of the converter is controlled by using proportional resonant controller that controls modulation index $\mathrm{M}$. The accurate extraction of the grid voltage phase angle and frequency is very important to ensure stable operation of gridconnected power converter. Comparison of PLL is done in [27]-[29] and as most promising are carried out Second-Order Generalized Integrator (SOGI) PLL and Park, the Park PLL is more difficult to implement therefore hybrid SOGI and Park based PLL is used.

For the inverter control is used sinusoidal PWM with added ST states via logic "OR" element [14]. Signal from the PR controller is compared with triangular modulation signal and traditional sinusoidal PWM is formed. The PI controller regulates shoot through duty cycle $\mathrm{D}$ to maintain desired input or battery power. Duty cycle D is added to the sinusoidal PWM and shoot through states is formed in which all of the transistors of the inverter are in on state

\section{SIMULATION RESULTS}

The results of the simulation study are shown in this section. The main goal of simulation is to shown pulse reduction possibility by using additional resonant controller as can be seen in Fig. 3. The PSIM model was used for simulation. The calculation of passive components of qZSI have been studied in [23]-[26]. In the simulation examples various values of passive components is used to show it influence to the current ripple. Switching frequency of the converter is $50 \mathrm{kHz}$, $\mathrm{R}_{\mathrm{BAT}}=0,5 \Omega$, parasitic resistance of the inductors are equal to $0,1 \Omega$.

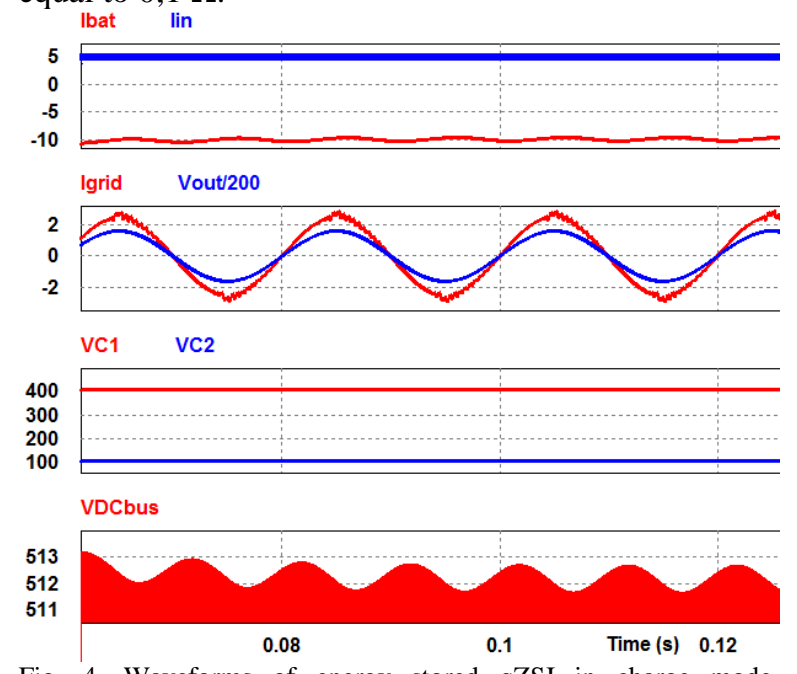

Fig. 4. Waveforms of energy stored qZSI in charge mode $\mathrm{L}_{1}=\mathrm{L}_{2}=1000 \mu \mathrm{H}, \mathrm{C}_{1}=\mathrm{C}_{2}=4000 \mu \mathrm{F}, \mathrm{V}_{\mathrm{IN}}=200 \mathrm{~V}, \mathrm{~V}_{\mathrm{BAT}}=50 \mathrm{~V}$ without current ripple compensation 

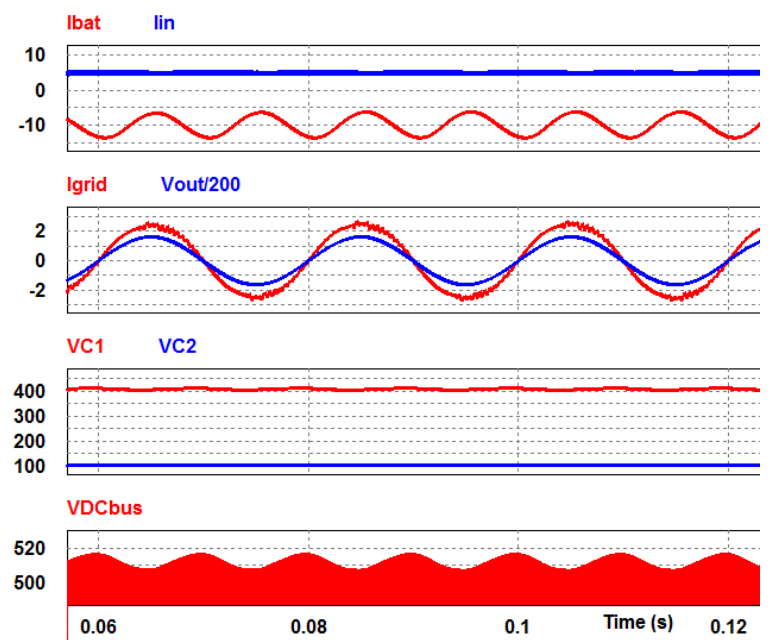

Fig. 5. Waveforms of energy stored qZSI in charge mode $\mathrm{L}_{1}=\mathrm{L}_{2}=1000 \mu \mathrm{H}, \mathrm{C}_{1}=\mathrm{C}_{2}=1000 \mu \mathrm{F}, \mathrm{V}_{\mathrm{IN}}=200 \mathrm{~V}, \mathrm{~V}_{\mathrm{BAT}}=50 \mathrm{~V}$ without current ripple compensation

Figures 4. and 5. shows simulation results that shows waveforms of the qZSI with large capacitance and in case if value of capacitance is 4 times reduced. The input current have low ripples as the regulator regulates duty cycle to maintain this current constant. Whereas the battery current ripple is determined by capacitor value. If the capacitance is reduced the battery current ripple increases.
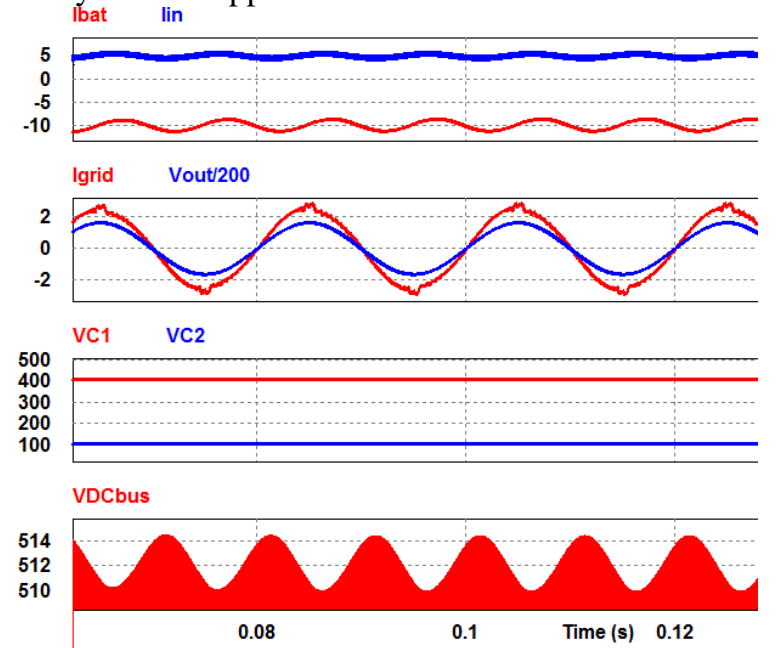

Fig. 6. Waveforms of energy stored qZSI in charge mode $\mathrm{L}_{1}=\mathrm{L}_{2}=1000 \mu \mathrm{H}, \mathrm{C}_{1}=\mathrm{C}_{2}=1000 \mu \mathrm{F}, \mathrm{V}_{\mathrm{IN}}=200 \mathrm{~V}, \mathrm{~V}_{\mathrm{BAT}}=50 \mathrm{~V}$ with battery current ripple compensation

Fig. 6 shows simulation results in case if resonant current ripple suppression controller is used. As can bee seen the current ripples can be reduced to the nearly as in case if both of the capacitors are with 4 times larger capacitance. The input current ripples is only a little bit bigger. The battery current ripples can be reduced even more if the coefficient of resonant control is bigger but then the input current ripple is significant and PI controller can become unstable.

\section{CONCLUSIONS}

In the energy stored qZSI the size of the capacitors can be reduced by using $100 \mathrm{~Hz}$ ripple suppression control method. The control is realized by means of the resonant control of battery current ripple. The ripple suppression have limitations as by reducing battery power ripples the input power ripples becomes higher. This method does not need any additional costs only algorithm by means of digital control must be implemented therefore even minor current ripple reduction gives benefit. Active power decoupling method for ripple reduction must be analyzed as alternative, it is obvious disadvantage that additional passive and active elements will be needed.

\section{ACKNOWLEDGEMENT}

This research work has been supported by Latvian Council of Science (Grant 673/2014).

\section{REFERENCES}

[1] B. Singh, B. N. Singh, A. Chandra, K. Al-Haddad, A. Pandey, and D. P. Kothari, "A review of single-phase improved power quality AC-DC converters," IEEE Transactions on Industrial Electronics, vol. 50, no. 5, pp. 962-981, Oct. 2003.

[2] W. Li, Y. Gu, H. Luo, W. Cui, X. He, and C. Xia, "Topology Review and Derivation Methodology of Single-Phase Transformerless Photovoltaic Inverters for Leakage Current Suppression," IEEE Transactions on Industrial Electronics, vol. 62, no. 7, pp. 4537-4551, Jul. 2015.

[3] N. Zhang, D. Sutanto, and K. M. Muttaqi, "A review of topologies of three-port DC-DC converters for the integration of renewable energy and energy storage system," Renewable and Sustainable Energy Reviews, vol. 56, pp. 388-401, Apr. 2016.

[4] O. Husev et al., "Comparison of Impedance-Source Networks for Two and Multilevel Buck -Boost Inverter Applications," IEEE Transactions on Power Electronics, vol. 31, no. 11, pp. 7564-7579, Nov. 2016.

[5] A. Battiston, J. P. Martin, E. H. Miliani, B. Nahid-Mobarakeh, S. Pierfederici, and F. Meibody-Tabar, "Comparison Criteria for Electric Traction System Using Z-Source/Quasi Z-Source Inverter and Conventional Architectures," IEEE Journal of Emerging and Selected Topics in Power Electronics, vol. 2, no. 3, pp. 467-476, Sep. 2014.

[6] M. Shen, A. Joseph, J. Wang, F. Z. Peng, and D. J. Adams, "Comparison of Traditional Inverters and Z -Source Inverter for Fuel Cell Vehicles," IEEE Transactions on Power Electronics, vol. 22, no. 4, pp. 1453-1463, Jul. 2007.

[7] W. T. Franke, M. Mohr, and F. W. Fuchs, "Comparison of a Zsource inverter and a voltage-source inverter linked with a DC/DC-boost-converter for wind turbines concerning their efficiency and installed semiconductor power," in 2008 IEEE Power Electronics Specialists Conference, 2008, pp. 18141820.

[8] J. Zeng, W. Qiao, C. Wei, and L. Qu, "A soft-switched threeport single-stage inverter for photovoltaic-battery systems," in 2015 IEEE Energy Conversion Congress and Exposition (ECCE), 2015, pp. 4568-4573.

[9] D. Sun, B. Ge, X. Yan, H. Abu-Rub, D. Bi, and F. Z. Peng, "Impedance design of quasi-Z source network to limit double fundamental frequency voltage and current ripples in singlephase quasi-Z source inverter," in 2013 IEEE Energy Conversion Congress and Exposition, 2013, pp. 2745-2750.

[10] Y. Liu, H. Abu-Rub, B. Ge, F. Blaabjerg, O. Ellabban, and P. C. Loh, "Design of Z-Source and Quasi-Z-Source Inverters," in Impedance Source Power Electronic Converters, WileyIEEE Press, 2016, p. 424-.

[11] Y. Liu, B. Ge, H. Abu-Rub, and D. Sun, "Comprehensive Modeling of Single-Phase Quasi-Z-Source Photovoltaic Inverter to Investigate Low-Frequency Voltage and Current 
Environment. Technology. Resources, Rezekne, Latvia Proceedings of the $11^{\text {th }}$ International Scientific and Practical Conference. Volume III, 154-158

Ripple," IEEE Transactions on Industrial Electronics, vol. 62, no. 7, pp. 4194-4202, Jul. 2015.

[12]Z. Qin, Y. Tang, P. C. Loh, and F. Blaabjerg, "Benchmark of $\mathrm{AC}$ and DC Active Power Decoupling Circuits for SecondOrder Harmonic Mitigation in Kilowatt-Scale Single-Phase Inverters," IEEE Journal of Emerging and Selected Topics in Power Electronics, vol. 4, no. 1, pp. 15-25, Mar. 2016.

[13] Y. Zhou, H. Li, and H. Li, "A Single-Phase PV Quasi-ZSource Inverter With Reduced Capacitance Using Modified Modulation and Double-Frequency Ripple Suppression Control," IEEE Transactions on Power Electronics, vol. 31, no. 3, pp. 2166-2173, Mar. 2016.

[14] Y. Li, W. Gao, J. Li, R. Zhang, and F. Fang, "Double line frequency ripple cancelling for single-phase quasi-Z-source inverter," in 2016 IEEE Energy Conversion Congress and Exposition (ECCE), 2016, pp. 1-6.

[15]L. Liivik, A. Chub, D. Vinnikov, and J. Zakis, "Experimental study of high step-up quasi-Z-source DC-DC converter with synchronous rectification," in 2015 9th International Conference on Compatibility and Power Electronics (CPE), 2015, pp. 409-414.

[16]J. Khajesalehi, M. Hamzeh, K. Sheshyekani, and E. Afjei, "Modeling and control of quasi Z-source inverters for parallel operation of battery energy storage systems: Application to microgrids," Electric Power Systems Research, vol. 125, pp. 164-173, Aug. 2015

[17] Y. Liu, B. Ge, H. Abu-Rub, and F. Z. Peng, "Control System Design of Battery-Assisted Quasi-Z-Source Inverter for GridTie Photovoltaic Power Generation," IEEE Transactions on Sustainable Energy, vol. 4, no. 4, pp. 994-1001, Oct. 2013.

[18]B. Ge et al., "An Energy-Stored Quasi-Z-Source Inverter for Application to Photovoltaic Power System," IEEE Transactions on Industrial Electronics, vol. 60, no. 10, pp. 4468-4481, Oct. 2013.

[19] J. Anderson and F. Z. Peng, "Four quasi-Z-Source inverters," in 2008 IEEE Power Electronics Specialists Conference, 2008, pp. 2743-2749.

[20] Y. P. Siwakoti, F. Z. Peng, F. Blaabjerg, P. C. Loh, G. E. Town, and S. Yang, "Impedance-Source Networks for Electric Power Conversion Part II: Review of Control and Modulation Techniques," IEEE Transactions on Power Electronics, vol. 30, no. 4, pp. 1887-1906, Apr. 2015.

[21]I. Roasto, D. Vinnikov, J. Zakis, and O. Husev, "New ShootThrough Control Methods for qZSI-Based DC/DC Converters," IEEE Transactions on Industrial Informatics, vol. 9, no. 2, pp. 640-647, May 2013.
[22] Y. Li, J. Anderson, F. Z. Peng, and D. Liu, "Quasi-Z-Source Inverter for Photovoltaic Power Generation Systems," in Twenty-Fourth Annual IEEE Applied Power Electronics Conference and Exposition, 2009. APEC 2009, 2009, pp. 918924.

[23] W. Liang, B. Ge, Y. Liu, H. Abu-Rub, R. S. Balog, and Y. Xue, "Modeling, analysis, and impedance design of battery energy stored single-phase quasi-Z source photovoltaic inverter system," in 2016 IEEE Energy Conversion Congress and Exposition (ECCE), 2016, pp. 1-6.

[24] Y. Zhou, H. Li, and H. Li, "A Single-Phase PV Quasi-ZSource Inverter With Reduced Capacitance Using Modified Modulation and Double-Frequency Ripple Suppression Control," IEEE Transactions on Power Electronics, vol. 31, no. 3, pp. 2166-2173, Mar. 2016.

[25] S. A. Singh, N. A. Azeez, and S. S. Williamson, "Capacitance reduction in a single phase Quasi Z-Source Inverter using a hysteresis current controlled active power filter," in 2016 IEEE 25th International Symposium on Industrial Electronics (ISIE), 2016, pp. 805-810.

[26] Y. Liu, B. Ge, H. Abu-Rub, and F. Z. Peng, "Control System Design of Battery-Assisted Quasi-Z-Source Inverter for GridTie Photovoltaic Power Generation," IEEE Transactions on Sustainable Energy, vol. 4, no. 4, pp. 994-1001, Oct. 2013.

[27]I. Galkin and M. Vorobyov, "Optimizing of sampling in a lowcost single-phase instantaneous AC-grid synchronization unit with discrete calculation of derivative function," in IECON 2015 - 41st Annual Conference of the IEEE Industrial Electronics Society, 2015, pp. 004538-004543.

[28]I. Roasto, T. Jalakas, and O. Husev, "Modeling of gridconnected quasi-Z-source series resonant topology based microinverter," in 2016 10th International Conference on Compatibility, Power Electronics and Power Engineering (CPE-POWERENG), 2016, pp. 192-195.

[29]Y. Han, M. Luo, X. Zhao, J. M. Guerrero, and L. Xu, "Comparative Performance Evaluation of Orthogonal-SignalGenerators-Based Single-Phase PLL Algorithms \#x2014;A Survey," IEEE Transactions on Power Electronics, vol. 31, no. 5, pp. 3932-3944, May 2016.

[30]Y. Han, M. Luo, X. Zhao, J. M. Guerrero, and L. Xu, "Comparative Performance Evaluation of Orthogonal-SignalGenerators-Based Single-Phase PLL Algorithms \#x2014;A Survey," IEEE Transactions on Power Electronics, vol. 31, no. 5, pp. 3932-3944, May 2016 